Daniel S. Sitar PHD, Peter C. Duke MD, James A. Owen PH D, Lisa Berger MD, Paul A. Mitenko MD

\title{
Kinetic disposition of morphine in young males after intravenous loading and maintenance infusions
}

Loading and maintenance infusions of morphine sulfate were administered to 5 young male patients 23-34-yrold prior to elective surgery. Apparent steady-state plasma concentrations were achieved 30 minutes after the start of the drug infusion. The volume of distribution at steady-state $\left(2.43 \pm 0.48 \mathrm{~L} \cdot \mathrm{kg}^{-1}\right)$, beta elimination rate constant $(0.700 \pm 0.162 / \mathrm{h})$ and plasma clearance $\left(l .66 \pm 0.33 \mathrm{~L} \cdot \mathrm{kg}^{-1} \cdot \mathrm{h}^{-1}\right)$ were similar to values previously determined in young healthy subjects receiving a single bolus infusion. These data confirm our findings concerning morphine disposition in healthy young subjects and demonstrate the feasibility of achieving predictable plasma concentrations of morphine for future assessment of pharmacodynamic/pharmacokinetic relationships for this drug.

\section{Key words}

ANALGESICS: morphine; PHARMACOKINETICS: distribution, clearance, elimination.

From the Clinical Pharmacology Section, Deparment of Medicine, and the Departments of Anesthesia, and Pharmacology and Therapeutics, University of Manitoba, Winnipeg, Manitoba.

Address correspondence to: Dr. D.S. Sitar, Clinical Pharmacology Section, 770 Bannatyne Avenue, Winnipeg, Man., R3E OW3.

This study was supported by grants from The Canadian Foundation for the Advancement of Clinical Pharmacology and the Manitoba Heart Foundation. Dr. Owen received a post-doctoral fellowship from the Medical Research Council of Canada.
We previously reported results of a study on age and the kinetic disposition of morphine after intravenous bolus infusions. ${ }^{1}$ The disposition constants we derived were somewhat different from those reported by others. ${ }^{2-5}$ Our data indicated a smaller apparent volume of distribution and an increased plasma clearance of morphine. We attribute this difference to the fact that previous studies utilized a radioimmunoassay which is susceptible to interference by morphine-3-glucuronide. ${ }^{6}$ Our study utilized a specific extraction and chromatographic method. ${ }^{7}$ Since kinetic data are only useful if they can be used to predict drug concentrations in patients, we administered loading and maintenance infusions of morphine sulfate to young male patients prior to elective surgery. Doses based on our previous kinetic disposition data were used to produce predictable steady-state plasma concentrations of the drug. The results of this investigation are presented below.

\section{Methods}

\section{Patient selection}

Five male subjects, 23-34 years old, who weighed $67-97 \mathrm{~kg}$, were enrolled in the study. They were unmedicated patients who were scheduled for elective surgery. This study was approved by the University of Manitoba Faculty Committee on the Use of Human Subjects in Research, and informed consent was obtained from all volunteers. Routine laboratory investigations, including haemoglobin concentration, total white blood cell and platelet counts, and serum glucose, urea nitrogen, creatinine, protein, albumin, glutamic oxaloacetic trans- 
aminase, glutamic pyruvic transaminase, lactic dehydrogenase and alkaline phosphatase were done to confirm normal values for age, especially for hepatic and renal function.

\section{Study design}

All studies were conducted in an operating theatre in the morning and prior to surgery. Morphine sulfate was administered by two infusion pumps, one of which was used for the loading dose and the other for a simultaneous maintenance infusion through an indwelling catheter in a forearm vein. Subjects were recumbent throughout the study. The drug dose was calculated to achieve predicted steady-state concentrations in plasma based upon our previous bolus infusion experiments in young healthy volunteers." The dose regimens were chosen to produce two different steady-state plasma concentrations of morphine in each patient. By repeating the loading dose and doubling the maintenance infusion rate, the morphine plasma concentration was expected to double after the second loading dose.

Target concentrations of 32 and $64 \mathrm{ng} \cdot \mathrm{ml}^{-1}$ were initially chosen, and using the relationship plasma concentration at steady-state $\left(\mathrm{C}_{\mathrm{ss}}\right)=$ infusion rate $\left(\mathrm{K}_{0}\right)$ /clearance $\left(\mathrm{Cl}_{\mathrm{p}}\right)$, maintenance infusion rates of 0.068 and $0.137 \mathrm{mg} \cdot \mathrm{kg}^{-1} \cdot \mathrm{h}^{-1}$ were calculated along with corresponding loading doses of $0.19 \mathrm{mg} \cdot \mathrm{kg}^{-1}{ }^{8}$ The first patient who received this regimen became very sleepy with the second loading dose, and for the remaining four subjects the loading and maintenance doses were halved to avoid sedation. The target morphine concentrations for these patients were 16 and $32 \mathrm{ng} \cdot \mathrm{ml}^{-1}$, and the calculated loading and maintenance doses were $0.10 \mathrm{mg} \cdot \mathrm{kg}^{-1}$ and 0.034 and $0.068 \mathrm{mg} \cdot \mathrm{kg}^{-1} \cdot \mathrm{h}^{-1}$ respectively.

Loading doses were given over 15 minutes and each maintenance dose was continued over 60 minutes. At the end of the second hour, the administration of morphine sulfate was discontinued.

\section{Sample preparation and analyses}

Venous blood samples $(5 \mathrm{ml})$ were withdrawn from the opposite arm through an indwelling catheter into glass syringes at the following times: 0 (start of infusions), 5, 15, 30, 45, 60,75, 90, 105, 120 (end of infusions), 135, 150, 180, 240 and 300 minutes.

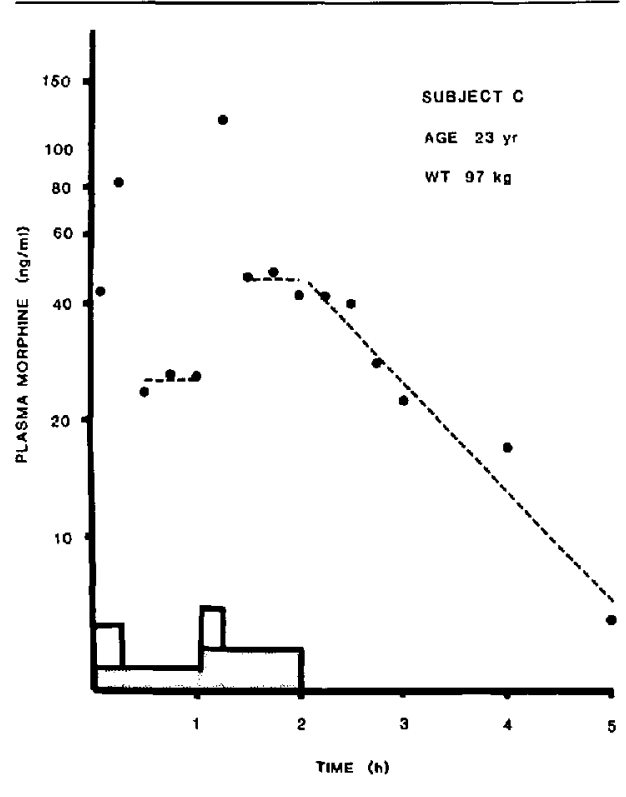

FIGURE Plasma morphine concentration-time curve for the subject who most closely represents the mean data from the low dose regimen. Morphine concentrations are presented as nanograms free base per milliliter of plasma. The shaded bars indicate the continuous maintenance infusion which was doubled between one and two hours after the start of the first loading dose. The open bars represent the two loading infusions which were given one hour apart.

Blood was immediately transferred to tubes containing sodium oxalate and mixed. Plasma was separated by centrifugation and stored $\left(-20^{\circ} \mathrm{C}\right)$ for subsequent morphine analysis by high performance liquid chromatography. ${ }^{7}$ All morphine concentrations are reported as the free base ( 86 per cent of weight as morphine sulfate).

\section{Data analyses}

The terminal elimination rate (beta) was determined by least squares linear regression analysis of the log of the plasma concentration of morphine versus time from the end of infusion at two hours to five hours after the start of the experiment. Volume of distribution $\left(\mathrm{Vd}_{\text {area }}\right)$ and plasma clearance $\left(\mathrm{Cl}_{\mathrm{p}}\right)$ were determined at one and two hours after the start of drug infusions assuming that steady-state was achieved. Plasma clearance was calculated as the maintenance infusion rate divided by the mean morphine plasma concentration from $30-60$ and 
TABLE I Pharmacokinetic disposition of morphine in young male patients after loading and maintenance doses

\begin{tabular}{|c|c|c|c|c|c|c|c|c|c|}
\hline \multirow[b]{2}{*}{ Subject } & \multirow[b]{2}{*}{$\begin{array}{l}\text { Age } \\
(y r)\end{array}$} & \multirow[b]{2}{*}{$\begin{array}{l}\text { Weight } \\
(k g)\end{array}$} & \multirow[b]{2}{*}{$\begin{array}{l}\text { Beta } \\
\left(h^{-1}\right)\end{array}$} & \multicolumn{3}{|c|}{$V d_{\text {area }} \ddagger\left(L \cdot \mathrm{kg}^{-1}\right)$} & \multicolumn{3}{|c|}{$C l_{p}\left(L \cdot k g^{-I} \cdot h^{-I}\right)$} \\
\hline & & & & $\begin{array}{l}t=30-60 \\
\min \end{array}$ & $\begin{array}{l}t=90-120 \\
\min \end{array}$ & $\begin{array}{l}\text { Model } \\
\text { independent } \\
\text { estimate }\end{array}$ & $\begin{array}{l}30-60^{*} \\
\min \end{array}$ & $\begin{array}{l}90-120^{*} \\
\min \end{array}$ & $\begin{array}{l}\text { Model } \dagger \\
\text { independent } \\
\text { esfimate }\end{array}$ \\
\hline A & 25 & 68 & 0.927 & 2.62 & 1.50 & 1.90 & 2.43 & 1.39 & 1.76 \\
\hline B & 24 & 67 & 0.728 & 2.34 & 2.75 & 3.02 & 1.70 & 2.00 & 2.20 \\
\hline C & 23 & 97 & 0.640 & 2.05 & 2.53 & 2.34 & 1.31 & 1.62 & 1.50 \\
\hline$D$ & 26 & 88 & 0.725 & 1.56 & 2.40 & 2.07 & 1.13 & 1.74 & 1.50 \\
\hline $\mathrm{E}$ & 34 & 80 & 0.480 & 3.54 & 3.92 & 2.83 & 1.70 & 1.88 & 1.36 \\
\hline Mean & 26 & 80 & 0.700 & 2.42 & 2.62 & 2.43 & 1.65 & 1.73 & 1.66 \\
\hline $\pm S D$ & 4 & 13 & 0.162 & 0.74 & 0.87 & 0.48 & 0.50 & 0.24 & 0.33 \\
\hline
\end{tabular}

${ }^{*} \mathrm{Cl}_{\mathrm{p}}=\mathrm{K}_{\mathrm{d}} / \mathrm{C}_{\mathrm{ss}}$.

$+\mathrm{Cl}_{\mathrm{p}}=$ Dose $/ \mathrm{AUC} \mathrm{C}_{0 \rightarrow \infty}$

$\mp V d_{\text {area }}=\mathrm{Cl}_{\mathrm{p}}$ beta.

90-120 minutes. $\mathrm{Vd}_{\text {aren }}$ was calculated as $\mathrm{Cl}_{\mathrm{p}}$ beta for these same times. Using model independent equations, $\mathrm{Cl}_{\mathrm{p}}$ (dose/area under the plasma concentration vs time curve (AUC) from $\mathrm{t}=0 \rightarrow \infty$ ) and $\mathrm{Vd}_{\text {area }}\left(\mathrm{Cl}_{\mathrm{p}}\right.$ beta) were also calculated for the data overall. Area under the curve was determined by the trapezoidal method and residual area under the curve after the last data point was determined as plasma concentration/beta. ${ }^{9}$ Data in the text are presented as means $\pm \mathrm{SD}$. Means were compared by analysis of variance.

\section{Results}

A morphine concentration-time curve for the patient who most closely approximated the mean values of kinetic disposition in our study is presented in the Figure. These data were derived from the low dose regimen, i.e., loading doses of $0.1 \mathrm{mg} \cdot \mathrm{kg}^{-1}$ with maintenance doses of 0.034 and $0.068 \mathrm{mg} \cdot \mathrm{kg}^{-1} \cdot \mathrm{h}^{-1}$ of morphine sulfate. The morphine concentration in plasma stabilized within 30 minutes of the loading doses and declined exponentially after two hours when the drug infusion was stopped.

A summary of the kinetic disposition of morphine in the five subjects is presented in Table $I$. $\mathrm{Vd}_{\text {area }}$ and $\mathrm{Cl}_{\mathrm{p}}$ determined between 30-60 and 90-120 minutes during the infusion were similar and agreed with the overall estimate of these disposition constants calculated by model independent methods. Thus they were not different relative to the method or time of determination. The measured morphine plasma concentrations at apparent steady-state approximated the target concen-
TABLE II Comparison of observed plasma morphine concentrations at steady-state with predicted values based on model independent kinetic analysis of the plasma concentration versus time data from each volunteer (see Table I).

Subjects A-D received the low dose regimen. Subject E received a higher dose regimen

\begin{tabular}{|c|c|c|c|c|}
\hline \multirow[b]{2}{*}{ Subject } & \multirow{2}{*}{$\begin{array}{l}\text { Time } \\
\text { interval } \\
(\min )\end{array}$} & \multicolumn{3}{|c|}{$C_{s s}\left(n g \cdot m l^{-1}\right)$} \\
\hline & & Predicted & Derived & Observed \\
\hline \multirow[t]{2}{*}{ A } & $30-60$ & 16 & 16 & 14 \\
\hline & $90-120$ & 32 & 33 & 49 \\
\hline \multirow[t]{2}{*}{ B } & $30-60$ & 16 & 13 & 20 \\
\hline & $90-120$ & 32 & 26 & 34 \\
\hline \multirow[t]{2}{*}{$C$} & $30-60$ & 16 & 19 & 26 \\
\hline & $90-120$ & 32 & 39 & 42 \\
\hline \multirow[t]{2}{*}{$\mathrm{D}$} & $30-60$ & 16 & 19 & 30 \\
\hline & $90-120$ & 32 & 39 & 39 \\
\hline \multirow{2}{*}{$\begin{array}{l}\text { Mean } \\
\pm S D\end{array}$} & $30-60$ & 16 & $17 \pm 3$ & $23 \pm 7$ \\
\hline & $90-120$ & 32 & $34 \pm 6$ & $41 \pm 6$ \\
\hline \multirow[t]{2}{*}{$\mathbf{E}$} & $30-60$ & 32 & 43 & 40 \\
\hline & $90-120$ & 64 & 86 & 73 \\
\hline
\end{tabular}

trations as predicted by our previous study, and of course closely agreed with those derived from the kinetic parameters found for each individual (Table II). As well, Table III indicates that the kinetic parameters observed in this study also agree with those determined in our previous study. ${ }^{1}$

\section{Discussion}

Our data indicate that steady-state concentrations for morphine were achieved within 30 minutes of 
TABLE III Comparison of the pharmacokinetic disposition of morphine after intravenous bolus and maintenance infusions compared to a single bolus infusion in young subjects. Data are presented as ranges or as means $\pm \mathrm{SD}$

\begin{tabular}{lll}
\hline & $\begin{array}{l}\text { Bolus infusion* } \\
(13) \dagger\end{array}$ & $\begin{array}{l}\text { Loading and maintenance } \\
\text { infusions\$(5) } \dagger\end{array}$ \\
\hline Age $(\mathrm{yr})$ & $23-28$ & $23-34$ \\
Weight $(\mathrm{kg})$ & $55-93$ & $67-97$ \\
$\mathrm{Vd} \mathrm{d}_{\text {area }}\left(\mathrm{L} \cdot \mathrm{kg}^{-1}\right)$ & $2.73 \pm 0.55 \ddagger$ & $2.43 \pm 0.48$ \\
$\mathrm{Cl}_{\mathrm{p}}\left(\mathrm{L} \cdot \mathrm{kg}^{-1} \cdot \mathrm{h}^{-1}\right)$ & $2.02 \pm 0.30$ & $1.66 \pm 0.33$ \\
$\operatorname{Beta}(\mathrm{h})$ & $0.77 \pm 0.20$ & $0.70 \pm 0.16$ \\
\hline
\end{tabular}

*Data from reference 1.

†Number of experimental subjects.

$\neq$ Data recalculated from reference.

$\S \mathrm{Vd}_{\mathrm{area}}$ and $\mathrm{Cl}_{\mathrm{p}}$ data from model independent determinations. See Table I.

the start of the loading dose (Figure), and that these concentrations agreed reasonably well with target concentrations based on our previous data. As Tables II and III indicate, there are no statistically significant differences in any of the kinetic constants for the two methods of morphine administration in young, healthy subjects. If steadystate had not been achieved, estimations of $\mathrm{Cl}_{\mathrm{p}}$ and $\mathrm{Vd}_{\text {area }}$ would have been different, depending on the time and method used for their determination. Thus the present studies confirm our previously reported kinetic data using a specific chemical assay for morphine and demonstrate that these data are appropriate for the determination of dosage regimens which can produce predictable plasma morphine concentrations in man.

It is of interest that this study confirms our previous finding that plasma clearance of morphine exceeds hepatic blood flow $\left(1.26 \mathrm{~L} \cdot \mathrm{kg}^{-1} \cdot \mathrm{h}^{-1}\right) .{ }^{10}$ Other data suggest that the kidney is important for the conjugation of morphine with glucuronic acid, and this extrahepatic metabolic site probably accounts for the discrepancy between hepatic blood flow and plasma clearance of morphine. ${ }^{11.12}$

Our observed plasma concentrations of morphine at apparent steady-state were slightly higher than predicted from our previous data. ${ }^{1}$ This difference may be explained by the fact that plasma clearance of morphine in these five volunteers was somewhat lower than in our previous study. This could be due to the fact that subjects were resting and recumbent in the present study and ambulatory in our previous investigation. Cardiac output would be expected to be lower at rest.

In conclusion, the present study confirms the feasibility of using morphine infusion regimens to assess relationships between plasma concentrations and effects in young adults. Our results are also supported by a recent report of a similar approach to the production of steady-state morphine plasma concentrations in young chidren. ${ }^{13}$

\section{Acknowledgements}

The authors thank Mrs. S. Trosky, R.N. for excellent technical assistance.

\section{References}

1 Owen JA, Sitar DS, Berger L, Brownell L, Duke $P C$, Mitenko PA. Age-related morphine kinetics. Clin Pharmacol Ther $1983 ; 34: 364-8$.

2 Berkowitz BA, Nagai SH, Yang JC, Hempstead J, Spector $S$. The disposition of morphine in surgical patients. Clin Pharmacol Ther 1975; 17: 629-35.

3 Sawe J, Dahlstrom B, Paalzow L, Rane A. Morphine kinetics in cancer patients. Clin Pharmacol Ther 1981; 30: 629-35.

4 Stanski DR, Greenblatt DJ, Lappas DG, KochWeser J, Lowenstein E. Kinetics of high-dose intravenous morphine in cardiac patients. Clin Pharmacol Ther 1976; 19: 752-6.

5 Stanski DR, Greenblatt DJ, Lowenstein E. The kinetics of intravenous and intramuscular morphine. Clin Pharmacol Ther 1978, 24: 52-9.

6 Boerner U, Abbott S, Roe RL. The metabolism of morphine and heroin in man. Drug Metab Rev 1975; 4: 39-73.

7 Owen JA, Sitar DS. Morphine analysis by high performance liquid chromatography. J Chromatogr 1983; 276: 202-7.

8 Greenblatt DJ, Koch-Weser J. Drug Therapy, Part 2, N Engl J Med 1975; 293: 964-70.

9 Greenblatt DJ, Koch-Weser J. Drug Therapy, Part 1, N Engl J Med 1975; 293: 702-5.

10 Altman PL, Dittmer DS. Respiration and circulation. Bethesda, MD, 1971, American Society for Experimental Biology, p. 428.

11 Moore A, Sear J, Baldwin D, et al. Morphine kinetics during and after renal transplantation. Clin Pharmacol Ther 1984; 34: 641-5. 
12 McQuay $H$, Moore A. Be aware of renal function when prescribing morphine. Lancet $1984 ; 2$ :

284-5.

13 Chinyanga $H M$, Vandeberghe $H$, MacLeod S, Soldin S, Endrenyi L. Assessment of immediate post-anaesthetic recovery in young children following intravenous morphine infusions, halothane and isoflurane. Can Anaesth Soc J 1984; 31: 28-35.

\section{Résumé}

Avant la chirurgie élective des perfusions de sulfate de morphine ont été administrés d̀ cinq jeunes patients âgés de 23 à 34 ans. Les concentrations plasmatiques stables ont été acquises 30 minutes après le début de la perfusion. Le volume de distribution $\left(2.43 \pm 0.48 \mathrm{~L} \cdot \mathrm{kg}^{-1}\right)$, la constante béta du taux d'élimination $(0.700 \pm 0.162 / \mathrm{h})$ et la clearance plasmatique $\left(1.66 \pm 0.33 \mathrm{~L} \cdot \mathrm{kg}^{-1} \cdot \mathrm{h}^{-1}\right)$ étaient similaires à des valeurs déterminées au préalable chez les jeunes sujets en bonne santé recevant un bolus unique. Ces données confirment nos résultats concernant la disposition de la morphine chez les jeunes sujets sains et démontrent la possibilité d'acquérir des concentrations plasmatiques prévisibles de morphine afin d' évaluer dans le futur la relation phamacokinétiquelphamacodynamique de cet agent. 